\title{
Evaluation of emamectin benzoate and substance EX against salmon lice in sea-ranched Atlantic salmon smolts
}

\author{
Ove Tommy Skilbrei ${ }^{1, *}$, Per Gunnar Espedal ${ }^{2}$, Frank Nilsen $^{2}$, Enrique Perez Garcia $^{1}$, \\ Kevin A. Glover ${ }^{1,2}$ \\ ${ }^{1}$ Institute of Marine Research, PO Box 1870 Nordnes, Bergen 5817, Norway \\ ${ }^{2}$ Department of Biology, Sea Lice Research Centre, University of Bergen, PO Box 7803, Bergen 5020, Norway
}

\begin{abstract}
Experimental releases of Atlantic salmon smolts treated with emamectin benzoate (EB) against salmon lice have previously been used to estimate the significance of salmon lice on the survival of migrating smolts. In recent years, the salmon louse has developed reduced sensitivity to EB, which may influence the results of such release experiments. We therefore tested the use of 2 anti-lice drugs: EB was administered to salmon smolts in high doses by intra-peritoneal injection and the prophylactic substance EX (SubEX) was administered by bathing. A third, untreated control group was also established. Salmon were challenged with copepodids of 2 strains of salmon lice (1 EB-sensitive strain and 1 with reduced EB-sensitivity) in mixed-group experimental tanks. At $31 \mathrm{~d}$ post-challenge, the numbers of pre-adult lice on treated fish were around $20 \%$ compared with the control fish, with minor or no differences between the 2 treatments and lice strains. Both treatments therefore appeared to give the smolts a high degree of protection against infestation of copepodids of salmon lice. However, significantly lower growth of the EB-treatment group indicates that bathing the fish in SubEX is less stressful for smolts than intraperitoneal injection of EB.
\end{abstract}

KEY WORDS: Aquaculture $\cdot$ Atlantic salmon $\cdot$ Salmo salar $\cdot$ Sea lice $\cdot$ Lepeophtheirus salmonis Emamectin benzoate $\cdot$ Substance EX

\section{INTRODUCTION}

The rapid development of the Atlantic salmon (Salmo salar) aquaculture industry, which is largely based upon rearing fish in marine net-pens, has not been without environmental challenges. Of these, farmed escaped salmon and genetic interactions with wild conspecifics (Skaala et al. 2006, Glover et al. 2012, 2013) and infestations of wild salmonids with the parasitic marine copepod Lepeophtheirus salmonis represent 2 of the most visible problems (Taranger et al. 2014).

The salmon louse is characterized by 8 developmental stages (Hamre et al. 2013). The first 2 nau-

\footnotetext{
${ }^{*}$ Corresponding author: ove.skilbrei@imr.no
}

plius stages are free-living in the plankton, followed by the free-swimming copepodid which attaches to the fish. Thereafter, the infective stages feed on the skin, subcutaneous tissue, mucus and plasma of their hosts and may cause physiological stress (Brandal et al. 1976, Skugor et al. 2008, Wagner et al. 2008, Krasnov et al. 2012). Ultimately, parasitic feeding leads to open wounds on the host, which, if untreated, are followed by osmoregulatory failure and ultimately death (Tully \& Nolan 2002).

Ten chemotherapeutants have been applied to control salmon lice infestation in salmonids reared on farms from the early 1980s to the present. One driver to introduce new agents has been reduced sensitivity

(C) The authors 2015. Open Access under Creative Commons by Attribution Licence. Use, distribution and reproduction are unrestricted. Authors and original publication must be credited. 
or development of resistance in lice to the treatments (reviewed in Torrissen et al. 2013). The avermectin emamectin benzoate (EB) (Slice $\left.{ }^{\circledR}\right)$, which is the latest introduced treatment, has been in use from 1999. The main use of avermectins in aquaculture is against infestations with ectoparasitic copepods, among them Calanus rogercresseyi, on farmed salmon in Chile (Bravo 2003), Salmincola californiensis in Chinook salmon (Johnson \& Heindel 2001) and Lernathropus kroyeri in sea bass (Athanassopoulou et al. 2001). However, bioassays (Westcott et al. 2008) have demonstrated reduced sensitivity to EB in louse strains in various countries (Lees et al. 2008a, b, Horsberg 2012, Igboeli et al. 2012, Carmichael et al. 2013, Espedal et al. 2013, Ljungfeldt et al. 2014), and a recent study demonstrated that genes influencing resistance to this chemical were rapidly spread among salmon lice on both sides of the Atlantic (Besnier et al. 2014).

Preventive treatment against salmon lice with EB has been used in sea-ranching experiments aiming to estimate the effect of salmon lice on the survival of migrating smolts in Ireland (Gargan et al. 2012, Jackson et al. 2013) and Norway (Skilbrei et al. 2013, Vollset et al. 2014). EB has usually been administrated orally (Slice $\left.{ }^{\circledR}\right)$, but observations of variable concentrations of EB in smolts (Skilbrei et al. 2008) stimulated the use of intra-peritoneal injections of EB (Glover et al. 2010) in one of the experimental release series from 2007 (Skilbrei et al. 2013). This technique offered opportunities to improve the control of administration and to increase the dosage of EB. Another chemotherapeutant, not yet available on the market, substance EX (SubEX), has also been used in sea-ranching experiments to study the effect of sea lice on salmon smolt survival in the marine environment (Hvidsten et al. 2007, Skilbrei et al. 2013).

Due to the elimination half-life of EB of ca. 9 to $12 \mathrm{~d}$ (Sevatdal et al. 2005, Skilbrei et al. 2008, Glover et al. 2010), the protected period is probably restricted to the first weeks or month post-release. This is the period of seaward migration, when released smolts move through the fjord and coastal areas where salmon farms are located and the probability of being infested with salmon louse is believed to be high (Bjørn et al. 2001, Krkošek et al. 2005). It is of vital importance for the interpretation of the results of such studies that the delousing agent is efficient, otherwise the potential difference in survival between treated and control groups is reduced and the effect of parasites is underestimated.

We report on a laboratory study in which salmon smolts were challenged with 2 laboratory strains of salmon lice, 1 with high and 1 with reduced sensitivity to EB. Our intentions were to test whether intraperitoneal injection of a high dosage of EB and bathing the smolts in a solution of SubEX would protect the smolts from being infested with salmon lice.

\section{MATERIALS AND METHODS}

\section{Treatment of fish}

Hatchery-reared 1 yr old smolt of the Dale River stock were transferred from Dale hatchery to the Institute of Marine Research on 12 June 2013. They were distributed in three 6001 fiberglass tanks with running freshwater. From 14 to 17 June the salinity was increased to 33 by gradually changing the water supply from fresh to full seawater. Seawater temperature was 8.8 to $9.1^{\circ} \mathrm{C}$ throughout the experiment.

On 23 June, a total of 254 smolts (mean length and weight: $206 \pm 11 \mathrm{~mm}$ and $93 \pm 15 \mathrm{~g}, \mathrm{n}=63$ samples) were randomly grouped in 3 treatment groups. Onethird of the fish was treated with EB, and one-third, with SubEX. A stock solution of EB was prepared in $400 \mu \mathrm{g} \mathrm{ml}^{-1}$ propylene glycol. EB was thereafter administered by intra-peritoneal injection at a dosage of $400 \mu \mathrm{g} \mathrm{kg}^{-1}$ fish (Glover et al. 2010). The SubEX fish were bathed in a $2 \mathrm{mg} \mathrm{l}^{-1}$ solution for $30 \mathrm{~min}$ in a 7501 aerated tank. Both treatment groups and the control fish were marked immediately after the treatments and were then mixed in four $1 \times 1 \mathrm{~m}$ square 6001 tanks (see Table 1). SubEX is currently in the process of being certified for use in commercial aquaculture. The composition of this anti-parasitic drug, which protects the fish for approximately 3 mo (E. Aksnes, Pharmaq, Norway, pers. comm.), will be released later.

\section{Lice production}

These experiments were conducted in Norway using strains of lice from the Atlantic which represent the sub-species Lepeophtheirus salmonis salmonis (Skern-Mauritzen et al. 2014). The lice that were used to challenge fish included an EB-sensitive and a reduced sensitivity strain that had been held in culture for several generations prior to this experiment (Hamre et al. 2009, Espedal et al. 2013). The EB-sensitive strain was LsGulen (Generation F21/F23), and the strain with reduced EB sensitivity was LsAustevoll (F18). LsAustevoll had previously been tested in a family-based experiment on sensi- 
tivity to this substance (Ljungfeldt et al. 2014) and in a genetic linkage-mapping study which identified a major influence of a small genomic region influencing tolerance to EB (Besnier et al. 2014). Both lice strains were reared using the facilities and techniques previously described in detail by Hamre et al. (2009).

\section{Challenge of fish with lice and sampling}

The fish were challenged with copepodids on 15 July 2013. At this stage, all 4 tanks contained salmon from all experimental groups (i.e. control, EB-injected and SubEX-treated fish). Two of the replicates were challenged with the EB-sensitive lice (LsGulen), while the other 2 replicates were challenged with the reduced-sensitivity strain (LsAustevoll) (see Table 1). The total number of copepodids delivered to each of the tanks was $\sim 70 \mathrm{smolt}^{-1}$, and this was estimated by the sampling procedure previously described (Hamre et al. 2009). Fish were starved $2 \mathrm{~d}$ before copepodid infection. Infection of tanks was performed by stopping the inlet water, dropping the water level to approximately $25 \%$ of its initial volume, and then aerating the water with small aquarium pumps and stones. The copepodids were then equally divided between their 2 respective replicate tanks. After $1 \mathrm{~h}$, the inlet water was once again reinstated. This procedure has been used successfully to infect salmon with lice in this facility (Glover et al. 2001, Glover \& Skaala 2006, Hamre et al. 2009). Following infection, the fish were fed once daily by hand on a standard Altlantic salmon commercial diet.

The experiment was ended on 15 August, $31 \mathrm{~d}$ after infection. Starting with the first tank, fish were netted 2 or 3 at a time and placed into individual anesthetic baths containing an overdose of benzocain. Once dead, the fish was given an additional sharp blow to the head to ensure it was dead before lice were removed from the fish and counted using forceps. Any lice remaining in the anasthetic bath, which had dropped off during sampling, were also included in the count for each fish. In addition to the total number of lice observed per fish, fish weight and length were recorded, and the fish clip code, revealing the fish's experimental group, was recorded.

The concentration of EB in the skin of the smolts was analyzed by ALS Food and Pharmaceutical, Chatteris, Cambridgeshire, UK.

The Norwegian Animal Research Authority approved intra-peritoneal injections of EB and adipose fin clipping of smolts and the challenge experiment (research permit number 2009/186329). The use of SubEX was approved by the Norwegian Medicines Agency.

\section{Bioassay}

In order to validate EB sensitivity status of the 2 lice strains used to infect the fish in this study, bioassays were performed on 5 and 6 November 2013. Bioassays were conducted as described by Espedal et al. (2013). The bioassay was set up with 5 different dosages of $\mathrm{EB}\left(50,100,200,400\right.$ and $800 \mu \mathrm{g} \mathrm{l^{-1 }}$ EB dissolved in methanol [100 $\mathrm{mg} \mathrm{l}^{-1}$ stock solution]) and seawater as a control. Of each concentration, a $50 \mathrm{ml}$ dilution was used in a glass Petri dish. The lice were incubated for $24 \mathrm{~h}$ at $11^{\circ} \mathrm{C}$ prior to evaluation. From LsGulen, young adult males (47 d post-challenge) were used, and from LsAustevoll young adult males (40 d post-challenge) were used.

Efficacy of EB was calculated as abundance of preadult lice in treated groups as a percentage of abundance in control groups.

\section{Statistics}

General linear models (GLM) (McCullagh \& Nelder 1989) were used to test whether the infestation of lice and final weights of fish differed between treatment groups and tanks. Infestation with lice was tested for absolute numbers of lice per fish and also for number of lice per gram fish as the dependent variable. Because of low lice counts, both calculations were repeated with $\log (x+1)$-transformed data. A Newman-Keuls test was used to test the differences between pairs of treatment groups. The GLM module of the statistical package STATISTICA (StatSoft, Release 5.1, v8.0) was applied for all calculations.

\section{RESULTS}

The bioassays verified that the LsGulen louse strain had a high sensitivity to EB compared with the LsAustevoll strain as expected from previous characterization of these laboratory strains (Espedal et al. 2013). In contrast with a survival rate of $50 \%$ of LsAustevoll lice at $400 \mu \mathrm{g} \mathrm{l}^{-1} \mathrm{~EB}$, few LsGulen lice survived $>50 \mu \mathrm{g} \mathrm{l}^{-1} \mathrm{~EB}$ (Fig. 1). The mean concentrations of EB in the skin of smolts were $164 \pm 53 \mu \mathrm{g} \mathrm{kg}^{-1}$ 


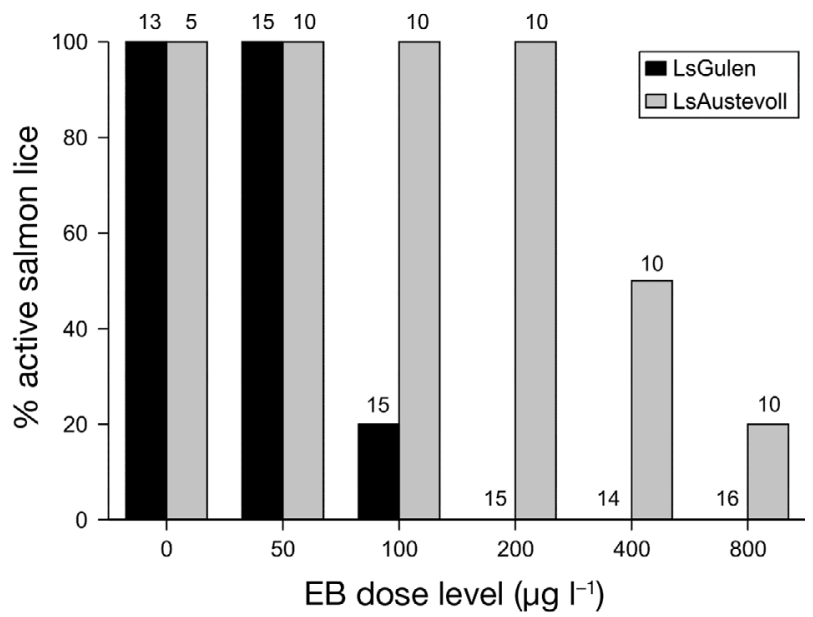

Fig. 1. Emamectin benzoate (EB) bioassay data on the 2 laboratory-reared strains of salmon louse Leophtheirus salmonis, the EB-sensitive strain (LsGulen) and the strain with reduced EB sensitivity (LsAustevoll). The bars show the percentage of normally active (non-responding) salmon lice after $24 \mathrm{~h}$ exposure to a given concentration of EB ( $x$-axis). The numbers of lice (n) in exposures are shown above bars

( $\mathrm{n}=5$, range: 95-230) $2 \mathrm{~d}$ prior to the challenge and $93 \pm 33 \mu \mathrm{kg}^{-1}(\mathrm{n}=15$, range: $54-161)$ at the end of the experiment.

Mean abundance of lice on untreated fish were $\sim 3$ to 8 times higher, and significantly higher than the infestation on treated fish irrespective of whether the actual counts of lice, number of lice per gram fish or $\log (x+1)$ transformation of these measurements were compared (Fig. 2, Tables $1 \& 2$ ). There was a trend that EB fish challenged with LsGulen lice had fewer lice (Fig. 2) (significant for 1 of the 4 GLM models; Table 2), and $50 \%$ of the efficacy values (Table 1), compared with the SubEX group. All other comparisons showed no statistical differences between the fish treated with SubEX and those treated with EB. Differences between parallel tanks also contributed to the variability in lice abundance, but did not appear to alter the effect of treatments (Fig. 2, Tables 1 \& 2).

At the end of the experiment, the fish receiving EB (mean $[ \pm$ SD] weight $103 \pm$ $20 \mathrm{~g}$ ) were significantly smaller than the SubEX $(117 \pm 24 \mathrm{~g})$ and control groups $(116 \pm 20 \mathrm{~g})$ (GLM: $F=4.88, \mathrm{p}_{\text {treatment }}<$ 0.0001, $\left.\mathrm{p}_{\text {tank }}=0.96\right)$. Compared with the mean weight of the fish at the start of the experiment, the EB fish gained $10 \mathrm{~g}$ during $52 \mathrm{~d}$, while the mean weight increases of the other groups were 24 and $23 \mathrm{~g}$.

\section{DISCUSSION}

This study demonstrated that the efficacy of bathing salmon smolts in a solution of SubEX was comparable to the effect of intra-peritoneal injection of a high dose of EB to significantly reduce the infestation of a sensitive and a reduced-sensitive strain of salmon lice. A more detailed evaluation of possible differences between the 2 chemotherapeutants was not possible due to the relatively low copepodid settlement success in the experiment.

Challenge studies are complicated by highly variable and unpredictable lice loss among common experimental tanks and a substantial rate of host transfer within tanks (Ritchie 1997, Hull et al. 1998, Hamre \& Nilsen 2011). Within the present study, the 3 treatment groups (EB, SubEX and control) were reared in common tanks in order to avoid tank effects on the experiment. However, this gave the lice
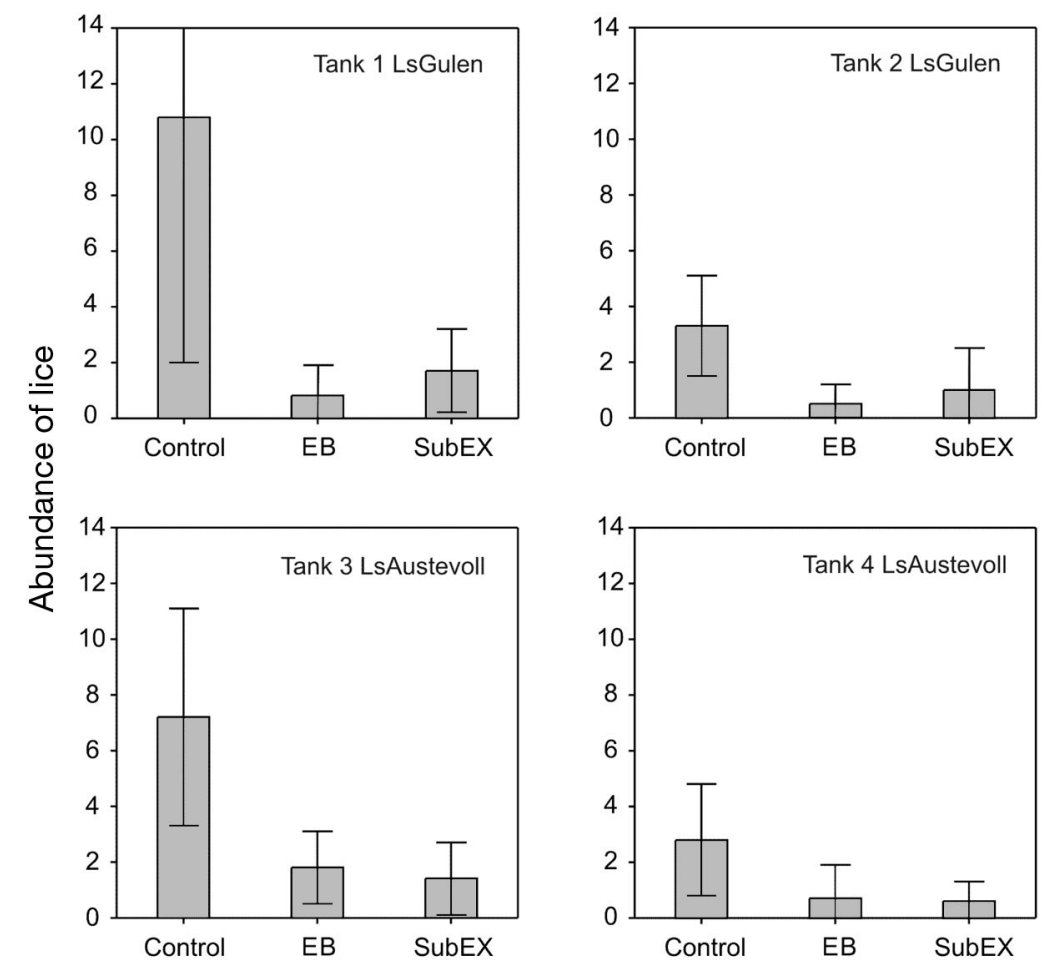

Fig. 2. Mean abundance $( \pm \mathrm{SD})$ of pre-adult lice on smolts in all 4 tanks at the end of the experiment on 15 August, $52 \mathrm{~d}$ after the challenges with copepodids of LsGulen and LsAustevoll 
Table 1. Overview of experimental set-up, treatment groups, lice infestations and the size of fish at the end of the experiment. U: unclipped fins; half: removal of half the adipose fin; cut: removal of the whole adipose fin. Efficacy is calculated as abundance of pre-adult lice in treated groups as a percentage of abundance in control groups

\begin{tabular}{|c|c|c|c|c|c|c|c|c|c|}
\hline $\begin{array}{l}\text { Tank } \\
\text { no. }\end{array}$ & Group & $\begin{array}{l}\text { Fin } \\
\text { clips }\end{array}$ & $\begin{array}{l}\text { Fish length } \\
(\mathrm{mm})\end{array}$ & $\begin{array}{c}\text { Fish weight } \\
(\mathrm{g})\end{array}$ & No. & Abundance & $\begin{array}{c}- \text { Lice - } \\
\text { Range }\end{array}$ & Prev. (\%) & $\begin{array}{c}\text { Efficacy } \\
(\%)\end{array}$ \\
\hline \multicolumn{10}{|c|}{ LsGulen (EB-sensitive) } \\
\hline \multirow[t]{3}{*}{1} & Control & U & $224 \pm 11$ & $117 \pm 21$ & 20 & $10.8 \pm 8.8$ & $2-39$ & 100 & \\
\hline & EB & Half & $216 \pm 1$ & $103 \pm 20$ & 19 & $0.8 \pm 1.1$ & $0-4$ & 53 & 7.8 \\
\hline & SubEX & Cut & $222 \pm 13$ & $115 \pm 24$ & 21 & $1.7 \pm 1.5$ & $0-5$ & 81 & 15.9 \\
\hline \multirow[t]{3}{*}{2} & Control & U & $225 \pm 10$ & $121 \pm 20$ & 21 & $3.3 \pm 1.8$ & $1-8$ & 100 & \\
\hline & EB & Half & $216 \pm 10$ & $101 \pm 16$ & 21 & $0.5 \pm 0.7$ & $0-2$ & 38 & 14.4 \\
\hline & SubEX & Cut & $223 \pm 12$ & $116 \pm 20$ & 20 & $1 \pm 1.5$ & $0-5$ & 50 & 30.0 \\
\hline \multicolumn{10}{|c|}{ LsAustevoll (reduced EB sensitivity) } \\
\hline \multirow[t]{3}{*}{3} & Control & U & $222 \pm 11$ & $115 \pm 20$ & 21 & $7.2 \pm 3.9$ & $0-17$ & 95 & \\
\hline & EB & Half & $216 \pm 10$ & $103 \pm 20$ & 21 & $1.8 \pm 1.3$ & $0-5$ & 86 & 24.5 \\
\hline & SubEX & Cut & $223 \pm 15$ & $119 \pm 25$ & 20 & $1.4 \pm 1.3$ & $0-4$ & 70 & 18.8 \\
\hline \multirow[t]{3}{*}{4} & Control & $\mathrm{U}$ & $220 \pm 9$ & $111 \pm 17$ & 20 & $2.8 \pm 2.0$ & $0-8$ & 95 & \\
\hline & EB & Half & $217 \pm 14$ & $104 \pm 24$ & 21 & $0.7 \pm 1.2$ & $0-4$ & 62 & 25.4 \\
\hline & SubEX & Cut & $224 \pm 13$ & $117 \pm 28$ & 18 & $0.6 \pm 0.7$ & $0-2$ & 50 & 21.8 \\
\hline
\end{tabular}

Table 2. Statistics of general linear models comparing the effect of treating smolts with emamectin benzoate (EB) or substance EX (SubEX) against the control group (C). The number of lice per fish, the number of lice per gram fish, as well as log $(x+1)$ transformations of these data are used as dependent variables. Post hoc comparisons between treatment groups were done by Newman-Keuls test

\begin{tabular}{|c|c|c|c|c|c|c|c|c|c|c|}
\hline \multirow{2}{*}{$\begin{array}{l}\text { Dependent } \\
\text { variable }\end{array}$} & \multicolumn{3}{|c|}{ - Whole model } & \multicolumn{4}{|c|}{ Parameters } & \multicolumn{3}{|c|}{ — Post hoc comparisons } \\
\hline & $F$ & $\mathrm{p}$ & $\mathrm{R}^{2}$ & $F_{\text {treat }}$ & $\mathrm{p}_{\text {treat }}$ & $F_{\text {tank }}$ & $\mathrm{p}_{\text {tank }}$ & $p_{\text {EB vs.SubEX }}$ & $\mathrm{p}_{\mathrm{Cvs. \textrm {EB }}}$ & $\mathrm{p}_{\mathrm{C} \text { vs.SubEX }}$ \\
\hline \multicolumn{11}{|l|}{ LsGulen } \\
\hline No. of lice & 24.4 & $<0.0001$ & 0.38 & 29.3 & $<0.0001$ & 14.9 & $<0.001$ & 0.43 & $<0.001$ & $<0.001$ \\
\hline $\log (x+1)$ no. of lice & 57.7 & $<0.0002$ & 0.59 & 75.7 & $<0.0001$ & 21.6 & $<0.0001$ & $<0.05$ & $<0.001$ & $<0.001$ \\
\hline No. of lice $g^{-1}$ & 34.3 & $<0.0003$ & 0.47 & 40.5 & $<0.0001$ & 22 & $<0.0001$ & 0.37 & $<0.001$ & $<0.001$ \\
\hline $\log (x+1)$ no. of lice $g^{-1}$ & 36.4 & $<0.0004$ & 0.48 & 43.3 & $<0.0001$ & 22.9 & $<0.0001$ & 0.34 & $<0.001$ & $<0.001$ \\
\hline \multicolumn{11}{|l|}{ LsAustevoll } \\
\hline No. of lice & 38 & $<0.0005$ & 0.49 & 43.5 & $<0.0001$ & 27.2 & $<0.0001$ & 0.63 & $<0.001$ & $<0.001$ \\
\hline $\log (x+1)$ no. of lice & 41.3 & $<0.0006$ & 0.51 & 46.7 & $<0.0001$ & 30.8 & $<0.0001$ & 0.49 & $<0.001$ & $<0.001$ \\
\hline No. of lice $g^{-1}$ & 35.6 & $<0.0007$ & 0.48 & 41.4 & $<0.0001$ & 24 & $<0.0001$ & 0.40 & $<0.001$ & $<0.001$ \\
\hline $\log (x+1)$ no. of lice $g^{-1}$ & 36.4 & $<0.0008$ & 0.48 & 42.4 & $<0.0001$ & 24.6 & $<0.0001$ & 0.38 & $<0.008$ & $<0.008$ \\
\hline
\end{tabular}

opportunity to transfer host group once they had reached the preadult stage. We therefore cannot exclude the possibility that lice movements between individual fish in the tanks may have influenced the results. If lice moved from control to treated fish, reduced treatment effects and lowered survival of the lice in the tank would be expected.

Bioassay information did not mirror the efficacy of EB in the challenge study, meaning that EB concentrations were not directly comparable between methods. However, it is important to note that the fish were medicated prior to infection and that the tolerance for copepodid and chalimus stages is not expected to be the same as the tolerance for the adult males that were used in the bioassay. The concentration of EB in the skin of the smolts, which dropped from a mean of 164 to $93 \mu \mathrm{g} \mathrm{kg}{ }^{-1}$ during the experiment, was less than half the $\mathrm{EC}_{50}$ value $\left(\sim 400 \mu^{-1}\right)$ of the louse strain with reduced sensitivity; still, the efficacy of the treatment was 8 to $14 \%$ after the lice challenge. This is in agreement with Saksida et al. (2013) who compared farm treatment data with bioassays and concluded that salmon lice in British Columbia were still sensitive to $\mathrm{EB}$, although $\mathrm{EC}_{50}$ values were relatively high (a mean of $\sim 175 \mathrm{ppb}$ for male lice). The short exposure $(24 \mathrm{~h})$ of male adult lice to EB in the bioassay compared with the constant exposure of copepodids feeding on the skin of smolts may be one reason for the difference in absolute EB levels. Besides, it is not known if or to what degree the tolerance of salmon lice to EB may depend on the stage of salmon lice. Some bioassays suggest that 
males have a higher tolerance than females (Igboeli et al 2012, Saksida et al. 2013), however, in a recent study, females (which are larger than males) displayed a higher survival rate in response to EB treatment in comparison with their age-matched brothers (Ljungfeldt et al. 2014). Therefore, the use of male lice in our bioassays may not necessarily be representative of other developmental stages. Furthermore, the $1 \mathrm{wk}$ age difference between the males may have influenced the comparison between the 2 strains. Despite these uncertainties, the most obvious explanation for the present results is that the dosage of EB required to significantly reduce settlement of copepodids is lower than the dosage needed to kill older stages that have already settled on fish. Interpretations of bioassay values and the sensitivity status of salmon louse strains also vary in the literature. While Saksida et al. (2013) present $\mathrm{EC}_{50}$ values well above 100 for presumably sensitive strains of lice, Horsberg (2012) uses an $\mathrm{EC}_{50}$ of $\sim 30 \mu \mathrm{g} \mathrm{l}^{-1}$ for sensitive strains and an $\mathrm{EC}_{50}>120 \mathrm{\mu g} \mathrm{l}^{-1}$ to classify strains with reduced sensitivity.

During the experimental period, the EB-treated fish grew less than the control and SubEX-treated fish. We do not know whether this is a side effect of the high dosage of EB, part of a physiological reaction to the physical injection of polypropylene glycol or a combined effect. Roy et al. (2000) found signs of reduced appetite in salmon $1 \mathrm{wk}$ after oral administration of EB in high-dose groups, but no clear evidence of negative effects in groups given an EB dose similar to the EB level in the smolts in the present study at the time of lice challenge. In sea-ranching experiments, there was no indication of reduced growth in grilse previously injected with high dosages of EB as smolts versus sham-injected controls (receiving only the carrier propylene glycol) (Skilbrei et al. 2013). High dosages of EB (triple-dose Slice ${ }^{\circledR}$ ) have also been used in a lice challenge study by Poley et al. (2013) who did not report any adverse treatment effects. However, it is challenging for sea-ranched smolts to adapt to the new environment, and they normally suffer from high mortality during initial post-smolt migration (Thorstad et al. 2012). Reduced growth indicates that peritoneal injection may influence the smolts negatively during this critical phase.

Data from experimental releases of salmon smolts treated with EB in River Dale from 2001 to 2010 have been used to estimate the environmental impact of salmon lice in western Norway (Skilbrei et al. 2013, Vollset et al. 2014). Due to variable results with the oral administration of Slice ${ }^{\circledR}$ (Skilbrei et al. 2008), inter-peritoneal injection of EB was used from 2007 onwards, and, at the same time, the dose delivered to the fish was increased from 50 to $400 \mathrm{\mu g} \mathrm{kg}^{-1}$ (Glover et al. 2010). Reduced sensitivity in some of the strains of lice collected at various fish farms along the coast were observed during this period, i.e. in 2008 and 2009 (Horsberg 2012, Espedal et al. 2013). During the survey in 2009 two-thirds of the strains displayed reduced sensitivity $\left(\mathrm{EC}_{50}>120 \mu \mathrm{g} \mathrm{l}^{-1}\right)$ and $44.5 \%$ were resistant $\left(\mathrm{EC}_{50}>300 \mu \mathrm{g} \mathrm{l}^{-1}\right.$ ) (Horsberg 2012).

Based on the present challenge study, we conclude that salmon smolts treated with EB and then released into the wild probably have a significant degree of protection against salmon lice for the first weeks upon entering seawater. This is despite reports that salmon lice now display reduced sensitivity to EB in many regions (Besnier et al. 2014), which can potentially reduce the efficacy of such treatments. Our results may indicate that copepodids are more sensitive towards EB than mobile stages. Dosages of EB that are too low to remove adult lice with a high resistance to EB may still be effective in reducing the settlement of copepodids. However, it is important to note that, because we used a high dosage of EB, our results cannot be automatically transferred to normal oral treatments of salmon-lice-infested fish on commercial fish farms where recommended doses of EB vary between 60 and $100 \mathrm{\mu g} \mathrm{kg}^{-1}$. Further development of resistance towards this and other treatments can be expected, and indeed has been observed, for example, in Scotland (Lees et al. 2008a,b). As such, bathing salmon smolts in a solution of SubEX may represent an alternative treatment in experimental releases where the relative influence of sea lice on marine salmonid mortality is to be estimated. The efficacy of SubEX was comparable to that of EB, and, unlike intra-peritoneal injections, there was no posttreatment depression in growth.

Acknowledgements. We are grateful for the assistance and also for the comments of Elin Aksnes and her staff at Pharmaq; they made this study possible. The study was carried out with the financial support of the Institute of Marine Research, while bioassays were performed at the Sea Louse Research Centre at the University of Bergen using their resources. We are very grateful for the valuable comments and proposals from 3 anonymous reviewers who helped to improve the paper.

\section{LITERATURE CITED}

Athanassopoulou F, Ragias V, Tavla J, Christofilloyannis P, Liberis N (2001) Preliminary trials on the efficacy and toxicity of ivermectin against Lernathropus kroyeri Van Beneden, 1851 in cultured sea bass Dicentrarchus labrax L. Aquacult Res 32:77-79 
Besnier F, Kent M, Skern-Mauritzen R, Lien S and others (2014) Human-induced evolution caught in action: SNParray reveals rapid amphi-Atlantic spread of pesticide resistance in the salmon ectoparasite Lepeophtheirus salmonis. BMC Genomics 15:937

Bjørn PA, Finstad B, Kristoffersen R (2001) Salmon lice infection of wild sea trout and Arctic char in marine and freshwaters: the effects of salmon farms. Aquacult Res 32: 947-962

Brandal PO, Egidius E, Romslo I (1976) Host blood: a major food component for the parasitic copepod Lepeophtheirus salmonis Kröyeri, 1838 (Crustacea: Caligidae). Norw J Zool 24:341-343

Bravo S (2003) Sea lice in Chilean salmon farms. Bull Eur Assoc Fish Pathol 23:197-200

Carmichael SN, Bron JE, Taggart JB, Ireland JH and others (2013) Salmon lice (Lepeophtheirus salmonis) showing varying emamectin benzoate susceptibilities differ in neuronal acetylcholine receptor and GABA-gated chloride channel mRNA expression. BMC Genomics 14:408

Espedal PG, Glover KA, Horsberg TE, Nilsen F (2013) Emamectin benzoate resistance and fitness in laboratory reared salmon lice (Lepeophtheirus salmonis). Aquaculture 416-417:111-118

Gargan PG, Forde G, Hazon N, Russell DJF, Todd CD (2012) Evidence for sea lice-induced marine mortality of Atlantic salmon (Salmo salar) in western Ireland from experimental releases of ranched smolts treated with emamectin benzoate. Can J Fish Aquat Sci 69:343-353

Glover KA, Skaala $\varnothing$ (2006) Temporal stability of sea louse Lepeophtheirus salmonis Kroyer populations on Atlantic salmon Salmo salar L. of wild, farm and hybrid parentage. J Fish Biol 68:1795-1807

Glover KA, Nilsen F, Skaala O, Taggart JB, Teale AJ (2001) Differences in susceptibility to sea lice infection between a sea run and a freshwater resident population of brown trout. J Fish Biol 59:1512-1519

Glover KA, Samuelsen OB, Skilbrei OT, Boxaspen K, Lunestad BT (2010) Pharmacokinetics of emamectin benzoate administered to Atlantic salmon (Salmo salar L.) smolts by intra-peritoneal injection. J Fish Dis 33:183-186

Glover KA, Quintela M, Wennevik V, Besnier F, Sørvik AGE, Skaala $\varnothing$ (2012) Three decades of farmed escapees in the wild: a spatio-temporal analysis of population genetic structure throughout Norway. PLoS ONE 7: e43129

Glover KA, Pertoldi C, Besnier F, Wennevik V, Kent M, Skaala Ø (2013) Atlantic salmon populations invaded by farmed escapees: quantifying genetic introgression with a Bayesian approach and SNPs. BMC Genet 14:74

- Hamre LA, Nilsen F (2011) Individual fish tank arrays in studies of Lepeophtheirus salmonis and lice loss variability. Dis Aquat Org 97:47-56

Hamre LA, Glover KA, Nilsen F (2009) Establishment and characterisation of salmon louse (Lepeophtheirus salmonis (Kroyer 1837)) laboratory strains. Parasitol Int 58: 451-460

> Hamre LA, Eichner C, Caipang CMA, Dalvin ST and others (2013) The salmon louse Lepeophtheirus salmonis (Copepoda: Caligidae) life cycle has only two chalimus stages. PLoS ONE 8:e73539

Horsberg TE (2012) Avermectin use in aquaculture. Curr Pharm Biotechnol 13:1095-1102

Hull MQ, Pike AW, Mordue AJ, Rae GH (1998) Patterns of pair formation and mating in an ectoparasitic caligid copepod Lepeophtheirus salmonis (Krøyer 1837): implications for its sensory and mating biology. Philos Trans R Soc Lond B Biol Sci 353:753-764

Hvidsten NA, Finstad B, Kroglund F, Johnsen BO, Strand R, Arnekleiv JV, Bjørn PA (2007) Does increased abundance of sea lice influence survival of wild Atlantic salmon post-smolt? J Fish Biol 71:1639-1648

> Igboeli OO, Fast MD, Heumann J, Burka JF (2012) Role of $\mathrm{P}$-glycoprotein in emamectin benzoate (SLICE (R)) resistance in sea lice, Lepeophtheirus salmonis. Aquaculture 344-349:40-47

> Jackson D, Cotter D, Newell J, McEvoy S and others (2013) Impact of Lepeophtheirus salmonis infestations on migrating Atlantic salmon, Salmo salar L., smolts at eight locations in Ireland with an analysis of lice-induced marine mortality. J Fish Dis 36:273-281

Johnson KA, Heindel JA (2001) Efficacy of manual removal and ivermectin gavage for control of Salmincola californiensis (Wilson) infestation of chinook salmon, Oncorhynchus tshawytscha (Walbaum), captive broodstocks. J Fish Dis 24:197-203

> Krasnov A, Skugor S, Todorcevic M, Glover KA, Nilsen F (2012) Gene expression in Atlantic salmon skin in response to infection with the parasitic copepod Lepeophtheirus salmonis, cortisol implant, and their combination. BMC Genomics 13:130

Krkošek M, Lewis MA, Volpe JP (2005) Transmission dynamics of parasitic sea lice from farm to wild salmon. Proc R Soc Lond B Biol Sci 272:689-696

> Lees F, Baillie M, Gettinby G, Revie CW (2008a) The efficacy of emamectin benzoate against infestations of Lepeophtheirus salmonis on farmed Atlantic salmon (Salmo salar L) in Scotland between 2002 and 2006. PLoS ONE 3:e1549

Lees F, Baillie M, Gettinby G, Revie CW (2008b) Factors associated with changing efficacy of emamectin benzoate against infestations of Lepeophtheirus salmonis on Scottish salmon farms. J Fish Dis 31:947-951

Ljungfeldt LE, Espedal PG, Nilsen F, Skern-Mauritzen M, Glover KA (2014) A common-garden experiment to quantify evolutionary processes in copepods: the case of emamectin benzoate resistance in the parasitic sea louse Leoeophtherius salmonis. BMC Evol Biol 14:108

McCullagh P, Nelder J (1989) Generalized linear models, 2nd edn. Chapman \& Hall, New York, NY

> Poley J, Purcell SL, Igboeli OO, Donkin A, Wotton H, Fast MD (2013) Combinatorial effects of administration of immunostimulatory compounds in feed and follow-up administration of triple-dose SLICE (R) (emamectin benzoate) on Atlantic salmon, Salmo salar L., infection with Lepeophtheirus salmonis. J Fish Dis 36:299-309

Ritchie G (1997) The host transfer ability of Lepeophtheirus salmonis (Copepoda: Caligidae) from farmed Atlantic salmon, Salmo salar L. J Fish Dis 20:153-157

- Roy WJ, Sutherland IH, Rodger HDM, Varma KJ (2000) Tolerance of Atlantic salmon, Salmo salar L., and rainbow trout, Oncorhynchus mykiss, to emamectin benzoate, a new orally administered treatment for sea lice. Aquaculture 184:19-29

Saksida SM, Morrison D, McKenzie P, Milligan B, Downey E, Boyce B, Eaves A (2013) Use of Atlantic salmon, Salmo salar L., farm treatment data and bioassays to assess for resistance of sea lice, Lepeophtheirus salmonis, to emamectin benzoate (SLICE (R)) in British Columbia, Canada. J Fish Dis 36:515-520 
Sevatdal S, Magnusson AJ, Ingebrigtsen K, Haldorsen R, Horsberg TE (2005) Distribution of emamectin benzoate in Atlantic salmon (Salmo salar L.). J Vet Pharmacol Ther 28:101-107

Skaala Ø, Wennevik V, Glover KA (2006) Evidence of temporal genetic change in wild Atlantic salmon, Salmo salar L., populations affected by farm escapees. ICES J Mar Sci 63:1224-1233

Skern-Mauritzen R, Torrissen O, Glover KA (2014) Pacific and Atlantic Lepeoptheirus salmonis (Krøyer, 1838) are allopatric subspecies: Lepeoptheirus salmonis salmonis and Lepeoptheirus s. oncorhynchi subspecies novo. BMC Genet 15:32

Skilbrei OT, Glover K, Samuelsen O, Lunestad BT (2008) A laboratory study to evaluate the use of emamectin benzoate in the control of sea lice in sea-ranched Atlantic salmon (Salmo salar L.). Aquaculture 285:2-7

Skilbrei OT, Finstad B, Urdal K, Bakke G, Kroglund F, Strand R (2013) Impact of early salmon louse, Lepeophtheirus salmonis, infestation and differences in survival and marine growth of sea-ranched Atlantic salmon, Salmo salar L., smolts 1997-2009. J Fish Dis 36:249-260

Skugor S, Glover KA, Nilsen F, Krasnov A (2008) Local and systemic gene expression responses of Atlantic salmon (Salmo salar L.) to infection with the salmon louse (Lepeophtheirus salmonis). BMC Genomics 9:498

Editorial responsibility: Stewart Johnson,

Nanaimo, British Columbia, Canada
Taranger GL, Svåsand T, Glover KA, Bjørn PA, Karlsen Ø and others (2014) Risk assessment of the environmental impact of Norwegian Atlantic salmon farming. ICES J Mar Sci 72:997-1021

$>$ Thorstad EB, Whoriskey F, Uglem I, Moore A, Rikardsen AH, Finstad B (2012) A critical life stage of the Atlantic salmon Salmo salar: behaviour and survival during the smolt and initial post-smolt migration. J Fish Biol 81: $500-542$

> Torrissen $\mathrm{O}$, Jones $\mathrm{S}$, Asche F, Guttormsen A and others (2013) Salmon lice-impact on wild salmonids and salmon aquaculture. J Fish Dis 36:171-194

$>$ Tully O, Nolan DT (2002) A review of the population biology and host-parasite interactions of the sea louse Lepeophtheirus salmonis (Copepoda: Caligidae). Parasitology 124:165-182

> Vollset KW, Barlaup BT, Skoglund H, Normann ES, Skilbrei OT (2014) Salmon lice increase age-at-maturity of Atlantic salmon (Salmo salar). Biol Lett 10:20130896

> Wagner GN, Fast MD, Johnson SC (2008) Physiology and immunology of Lepeophtheirus salmonis infections of salmonids. Trends Parasitol 24:176-183

> Westcott JD, Stryhn H, Burka JF, Hammell KL (2008) Optimization and field use of a bioassay to monitor sea lice Lepeophtheirus salmonis sensitivity to emamectin benzoate. Dis Aquat Org 79:119-131

Submitted: July 28, 2014; Accepted: November 25, 2014 Proofs received from author(s): March 26, 2015 